\title{
Crouching Bear and Hidden Dragon: The Limitations in the Sino-Russian Alliance
}

\author{
Maria (Mary) Papageorgiou ${ }^{1}$, Luis Fernando Correa da Costa $^{2}$, Mohammad Eslami ${ }^{3}$ \\ ${ }^{I} P h D(c)$, Department of Political Science and International Relations, University of Minho, Portugal, \\ gbamary@hotmail.com \\ ${ }^{2} P h D(c)$, Department of Economics, University of Minho,Portugal, lfcorreacosta@gmail.com \\ ${ }^{3} \mathrm{PhD}(\mathrm{c})$, Department of Political science and International relations, University of Minho, Portugal, \\ mamad.eslami.1390@gmail.com
}

\begin{abstract}
In the post-cold war era there has been a remarkable renewal and strengthening of SinoRussian relations, especially from 2000 onwards. Moscow and Beijing started renewing and enhancing their ties in security, trade, as well as diplomatic issues more vigorously. The close cooperation between the two countries is evident however the partnership hasn't advanced to an anti-hegemonic opposition bloc despite the opportunities that arise. Russia and China are two rising powers with a great geopolitical weight in the international system and their partnership constitutes a constant topic of analysis. Sino-Russian co-operation takes place on many levels from energy supplies, joint military exercises, trade agreements, arms sales and the establishment of new multilateral institutions (such as the Sanghai organization, BRICS New Development Bank and the Asian Infrastructure Investment Bank, AIIB) to a broad consensus on issues in international relations. However, the two powers haven't formed an actual alliance that could fundamentally alter the distribution of power in the international system.
\end{abstract}

KEYWORDS: China, Russia, strategic partnership, arms sales, energy trade, cooperation

\section{Introduction}

Sino-Russian relation has been raised to one of the most important research areas in international relations attracting a lot attention from academics to policy-makers around the world. Russia and China's have intensified their cooperation in a number of areas raising worries on a possible change in the current international system dynamics and the prominent question is whether their partnership will pass the test of time and whether they will enter into a military-political alliance that can shift the global balance of power. "Political and economic rapprochement is taking place between Russia and China in a number of fields: energy, arms production, trade in national currencies and strategic projects in transport and supporting infrastructure" (Malle 2017, 136). Particularly their energy trade and military cooperation has been increased notably in the last two decades. Sino-Russian co-operation takes place on many levels from energy agreements, joint military exercises, arms sales and the establishment of new multilateral institutions (such as the Shanghai organization, BRICS New Development Bank and the Asian Infrastructure Investment Bank, AIIB) to a broad consensus on issues in international relations and support in international fora.

China and Russia share similar worldviews on the international system and domestic affairs. They both advocate for a multipolar world system with UN having a greater role, the principle of "non-interference in state sovereignty and freedom from "western hegemony"' (Konings 2007, 341). Nonetheless, the relationship between Beijing and Moscow remains in flux prompting questions about the depth and the long term vitality of their co-operation but most importantly on the direction it will follow and particularly whether this combined effort will challenge USA hegemony.

There have been different categorizations of this particular partnership between China and Russia, it has been characterized as axis of convenience (Lo 2008), presidential pseudo alliance (Baev 2018) opportunistic (Weitz 2008) an illusion (Beaucamp,2015), strategic partners as stated in the Treaty of 2001, a limited, defensive, strategic partnership (Li 2007, 478), or an alliance in the making (Economist 1997, Allison 2018) while for Garnett 'Sino-Russian behavior is a particularly clear example of a response to U.S. power that is hardly limited to these two states"'(2001, 42). Nonetheless despite the conceptualization of the Sino-Russia relationship their rapprochement is 
evident and it shows dissatisfaction with Western policies. "Both countries seek to offset US military superiority without engaging with American power directly (Shanghai cooperation organization) counterbalancing US interests in Central Asia. The two powers have institutionalized these norms within the Shanghai Cooperation Organization, which they use to counterbalance US interests in Central Asia" (Fergusson 2012, 197).

However, the two powers haven't formed an actual alliance that could fundamentally alter the distribution of power in the international system. The main research question of this paper is Whether this partnership has been intensified throughout the years? The intensity of this strategic partnership thought the last 18 years can provide us with an overall insight on developments, achievements and limitations. This paper will Illuminate the key drivers of Sino-Russian strategic cooperation giving special attention points of friction and to asymmetries in the bilateral relationship posed by the structure of the international system itself.

The periods (are calculated according to the days of elections as per follow 26 March 2000, 12 March 2004, 2 March 2008, 4 March 2012 and 18 March 2018 (source: OSCE)) under which our analysis will be divided mark Vladimir Putin terms in power from his first presidential election from 2000 till 2004, the second presidential term from 2004 till 2008, the period of him acting as Prime Minister of Russia, maintaining his political dominance (Chivers 2008) from 2008 till 2012 and lastly its third presidential term from 2012 till 2018.

The areas of cooperation that will be included is economic activities focus mainly on trade specifically on energy, and on military arms sales and joint military exercises. A significant amount of literature has been devoted to Sino-Russian military cooperation however that does not sufficiently demonstrate how much and how consistently the military cooperation between these two countries has increased in the post-cold war period (Korolev 2018). The same is also attributed on the energy cooperation as the cornerstone of this bilateral relationship. Thus, most approach when examining the Sino-Russian partnership lacking a holistic approach on the areas the cooperation is developed, the period it is formed and its intensity from time to time.

This paper will attempt to provide an overall approach based on measurable indicators of cooperation to see the trends and the intensity of cooperation in periods and in particular how it was influenced by certain events, Ukraine, Crimea, Syria and the US-China trade war.

\section{Historical background and partnership building}

In the post-cold war era there has been a remarkable renewal and strengthening of Sino-Russian relations, especially from 2000 onwards. Moscow and Beijing started renewing and enhancing their ties in security, trade, as well as diplomatic issues more vigorously and despite their great differences in the cultural identity and temperament, the two countries share common borders longer than 4,000 km and one common past (Oznobishchev 2017).

China-Russia rapprochement is not a product of 2000's and the first approach "lies in the 1980s, as Soviet president Mikhail Gorbachev and Chinese premier Deng Xiaoping sought to overcome decades of ideological, military, and political mistrust and competition" (Garnet 2010, 41). Since Mikhail Gorbachev's visit to Beijing in 1989, Moscow's relations with China have grown continually stronger (Bellacqua 2010). The materialized development of the Sino-Russian strategic partnership dates back to 1996 when Yeltchin used the term on a joint Sino-Russian statement (Li 2007, 479). "The Russian-Chinese relationship has been strengthening since the signing of the 'Treaty of Good neighborliness, Friendship and Co-operation' in 2001" (Portyakov 2010,2 ) and besides reaching an agreement on their common borders engaged in a series of common trade agreements and joints endeavors showcasing their will to create a multipolar world by limiting western interventions. For some authors one of the most dramatic diplomatic turnarounds in the past decade is the deepening of Sino-Russian strategic studies (Garnett 2001) that turns West's focus to the developments in the East. 


\section{Military cooperation}

Military cooperation between China and Russia has been strengthened particularly after the resolution of the borders dispute in 2001 and overcoming the accusation Russia has made against China in 2003 that was attempting to replicate its arsenal technology. Since then "the two have held high-level discussions on international security, negotiated important security-related agreements, conducted joint military exercises, and perhaps most strikingly engaged in large-scale arms trade" (Scharwtz 2014, 1). "The evolution of the China-Russia military relationship toward a higher level of cooperation and coordination is evident in the three main areas of bilateral defense engagement: (1) military exercises, (2) military-technical cooperation, and (3) high-level military-to-military contacts" (Meick 2017, 5).

Arms sales is an important element of the Sino-Russian strategic partnership with China being the largest importer of Russian military equipment during 1999 to 2006 reaching nearly 2 billion USD per year from 1999-2005 (Weezerman 2017). Another important aspect that the two countries seem to strengthen their partnership is on joint military exercises, which the use "to demonstrate their increasing military capabilities and the strength of China-Russia defense ties to the international community, particularly the United States and countries in the Asia Pacific" (Meick 2017, 6).

In the next tables there is depiction of the intensity of the bilateral arms sales trade between the two countries as divided in the distinct periods of analysis (see table 1, graph 1).

Table 1: Change in imports of weapons to China from Russia (in percentage per period)

\begin{tabular}{cc}
\hline Period & Imports to China from Russia \\
\hline $2000-2004$ & $29,40 \%$ \\
$2004-2008$ & $-52,44 \%$ \\
$2008-2012$ & $-52,18 \%$ \\
$2012-2017$ & $18,65 \%$ \\
\hline Total $2000-2017$ & $-61,50 \%$
\end{tabular}

Source: SIPRI

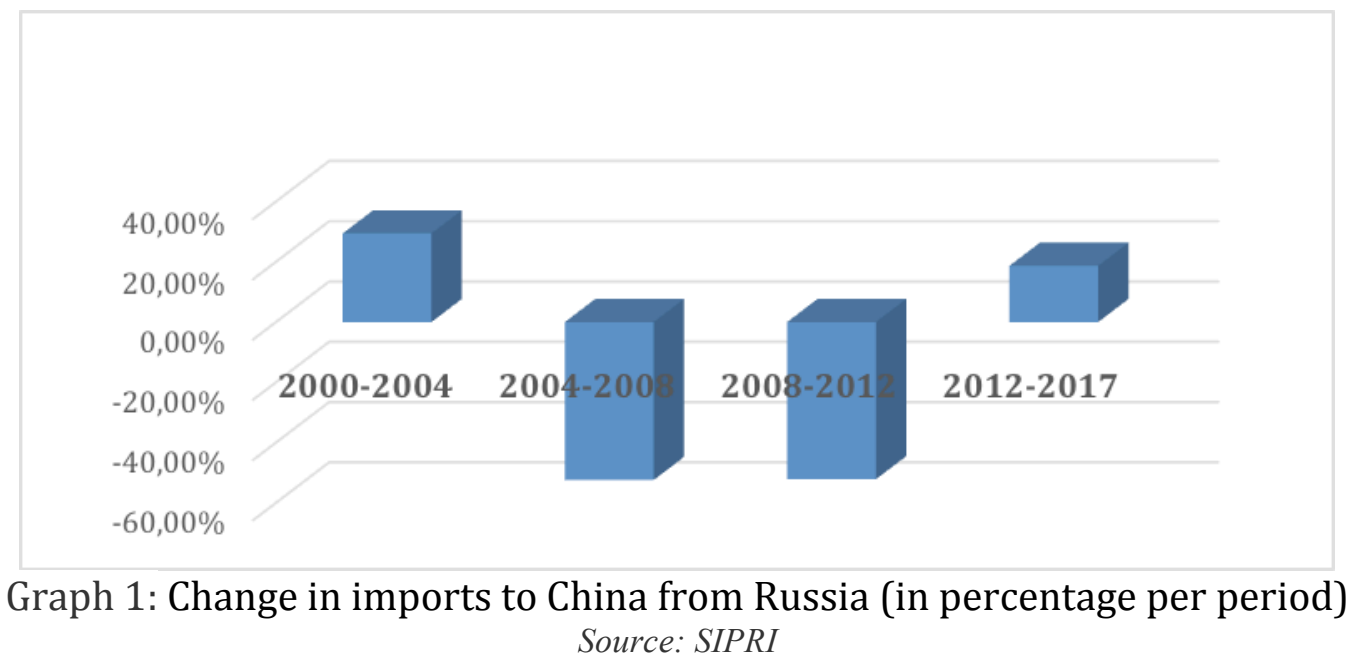

According to the data provided the bilateral trade between the two countries seems to vary according to periods. The highest volume of which was employed in the first period of 2000 till 2004 with the next two periods present a negative relation with lower transactions that seems to balance again in the period between 2012 to 2017 but not reaching the level of the first period. 
Despite of enhanced cooperation since 2000, the data don't depict an intensified cooperation but quite the opposite. The period of 2008 till 2012 includes the economic crisis which resulted in a reduction in arms sales transactions, the war in Georgia and the Syrian war that didn't seem to increase the bilateral transactions.

The last period between 2014 concedes with the annexation of Crimea, Ukraine crisis and the trade war between China and USA however despite these opportunities to forge a closer partnership or intensify their cooperation we identify a cooperative but not convergent trend (see table 1). Russia's sales to China have decreased considerably, to less than US\$ 1 billion per year (SIPRI, Weezerman, 2017, Arms Transfers Database 1991-2011). Among the reasons for this decrease is that Russia was reluctant to provide China with more advanced (Weitz 2008) and China sought more sophisticated technology than Russia was willing to offer (De Haas 2013).

The overall exports to China from Russia since 2000 and by the year 2017 have decreased showcasing the China's shift away from Russian exports was in part linked to its own growing manufacturing capabilities while also rapidly transitioned into a major arms exporter (Wezeman 2017).

\section{Joint military exercises}

China and Russia have been associated in a series of military exercises since 2002 either under the aegis of SCO or on a bilateral level. The joint China-Russia military exercises provide several benefits to both countries that contribute to their security partnership (Weitz, 2015) and "can be regarded as an extension and thermometer of the overall relationship between the two countries" (De Haas 2013, 44)

Table 2: Military exercises (including naval)

\begin{tabular}{|c|c|c|c|}
\hline Period & $\begin{array}{c}\text { SCO with the } \\
\text { participation of } \\
\text { other members }\end{array}$ & $\begin{array}{c}\text { SCO Joint (only } \\
\text { Russia China) }\end{array}$ & Bilateral \\
\hline $2000-2004$ & 2 & 0 & 1 \\
\hline $2004-2008$ & 1 & 1 & 1 \\
\hline $2008-2012$ & 3 & 1 & 3 \\
\hline $2012-2018$ & 3 & 1 & 10 \\
\hline
\end{tabular}

Source: Adapted from Weitz 2015; Yu Bin 2014; Scobell, Ratner, and Beckley 2014; Blasko 2010

Since 2000 the two countries have continued on a regular basis their exercises under SCO as well as having stepped up the level of their joint military exercises especially on bilateral level showing an intensification in security (see table 2) and a "shift from arms transfers to direct military cooperation" (Schwatz 2014). However, these exercises have a dual purpose first to indicate a close cooperation with one another on joint war games unity not only in their borders is Asia Pacific but also in other regions of the world (Mediterranean, Baltic) as well as has served to gain more insight into the military capabilities of the other 'partner' (De Haas 2013).

\section{Energy}

The energy cooperation between China and Russia is the most distinct feature of their strategic partnership and has gained vigorous support from both governments. "The trade between the two countries began somehow increasing in the early 2000s due to the warming of political relations associated with signing the Treaty of Good Neighborliness and Friendly Cooperation in 2001" (Nezhnikova, Papelniuk, Gorokhova 2018).

From 2008 to 2016 Russian and Chinese companies signed several major oil and gas agreements, a period in which Moscow reassessed China as a future energy consumer and lifted bilateral cooperation to a new level (Roseth 2017). Among the most prominent agreements in SinoRussian bilateral energy cooperation is the ambitious agreement of the 21 May 2014 when "the China National Petroleum Corporation (CNPC), the country's largest integrated energy company, 
and Russian energy giant Gazprom, which controls Russia's export gas pipelines, finally signed a thirty-year, $\$ 400$ billion deal that will see as much as thirty-eight billion cubic meters (bcm) of Russian gas go to China annually from around 2018 to 2047" (Weitz 2014) that however hasn't started delivery yet.

Table 3: Growth rate of China's fuel imports from Russia-World

\begin{tabular}{lcc}
\hline Year & $\begin{array}{c}\text { Growth rate of imports } \\
\text { of fuels from Russia }\end{array}$ & $\begin{array}{c}\text { Growth rate of imports } \\
\text { of fuels from the World }\end{array}$ \\
\hline $2000-2004$ & $133,18 \%$ & $828,08 \%$ \\
$2004-2008$ & $282,23 \%$ & $194,19 \%$ \\
$2008-2012$ & $93,94 \%$ & $161,81 \%$ \\
$2012-2017$ & $-24,42 \%$ & $14,68 \%$ \\
\hline \multicolumn{2}{c}{ Source: UN Comtrade }
\end{tabular}

The figures in table 2 show that the imports of fuels of China from Russia increased through the four periods analyzed, except between the years of 2012 and 2017, when there was a reduction of $24,42 \%$ in the imports of the product. However, despite the increase in imports of fuels between 2000 and 2017, the growth rate has diminished along the years, whose peak was reached from 2004 to 2008 $(282,23 \%)$.Similarly, it is observed that China has imported fewer fuels from its worldwide trade partners, whereas the growth rate at the beginning of the last decade was $828 \%$, the growth rate between 2012 and 2017 suffered a dramatic drop at the amount of 14,68\% showing that energy ties between China and Russia are relatively modest and haven't reached an intensified level of cooperation (see table 3).

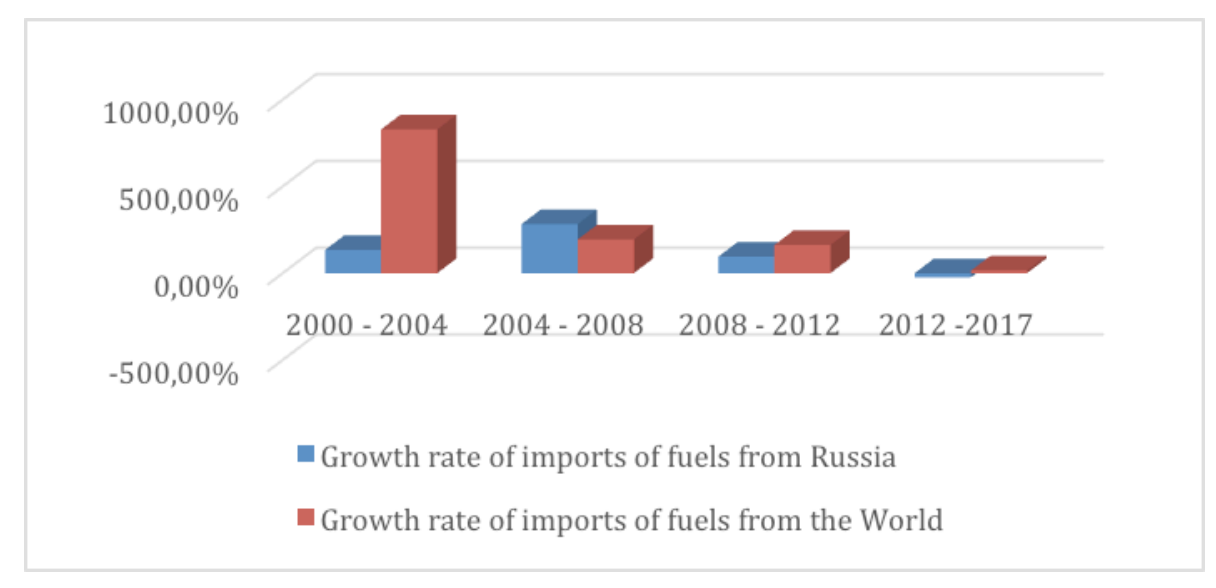

Graph 2: Growth rate of China's import fuels from Russia and the rest of World

Source: UN Comtrade

According to the periods under analysis we observe that the overall fuels imports to China where higher only during the period 2004-2008 surpassing imports for the rest parts of the world and also increased since the period 2000 to 2008 however the next two periods from 2008 to 2012 and from 2012 to 2018 indicate a lower import growth rate from both Russia and the world indicating not an intensified trade cooperation but a diminishing one (see table 3) considering as well that the 2014 gas deal hasn't been implemented yet. While at the same time Russia is looking for a fully diversified Asian energy market, extending beyond China to cover the wider Asia-Pacific region in Japan, South Korea and Southeast Asia (Lo and Rothman 2006). 


\section{Conclusion}

Sino-Russian relations have been friendly and cooperative over the past 18 years as a result of common strategic interests, facilitating arms sales, join forces in joint military exercises a built a seemingly winwin bilateral trade network.

The areas of cooperation discussed above showcase a trend of influx in Sino-Russian relations. Despite deepened cooperation since 2000, China and Russia haven't reached a steady level of partnership that would indicate a military alliance however has far exceeded to be called an axis of convenience. The trend indicators of the analysis show a dual approach of both rapprochement and constraint that represents the countries policies towards one another.

\section{References}

Allison, G. 2018. "China and Russia: A Strategic Alliance in the Making." The National Interest. Available at: https://nationalinterest.org/feature/china-and-russia-strategic-alliance-making-38727 Accessed 04 Mar. 2019.

Baev, P. 2018. "Three turns in the evolution of China-Russia presidential pseudo-alliance." Asia \& the Pacific Policy Studies 6(1): 4-18.

Beaucamp, Z. 2015. "There will never be a Russia-China alliance." Vox. Available online at: https://www.vox.com/2014/5/23/5741362/russia-china-pipedream-alliance. Accessed 09 Mar. 2019.

Bellacqua, J. 2010. The future of China-Russia relations. Lexington: The University Press of Kentucky.

Blasko, Dennis J. 2010. "People's Liberation Army and People's Armed Police Ground Exercises with Foreign Forces, 2002-2009." in Roy Kamphausen, David Lai, and Andrew Scobell (eds.), The PLA at Home and Abroad: Assessing the Operational Capabilities of China's Military, June 2010, 427-442. Available at: http://www.strategicstudiesinstitute.army.mil/pdffiles/PUB995.pdf.

Chivers, C. J. 2008. "Putin Is Approved as Prime Minister." New York Times, May 9, 2008. Available at https://www.nytimes.com/2008/05/09/world/europe/09russia.html.

De Haas, M. 2013. "Russian-Chinese Security Relations: Moscow's Threat from the East?" Clingendael.org. Available at: https://www.clingendael.org/sites/default/files/pdfs/20130327 rc securityrelations.pdf. Accessed 07 Mar. 2019.

Deng, Y. 2007. "Remolding great power politics:China's strategic partnerships with Russia, the European Union, and India.” Journal of Strategic Studies 30(4-5): 863-903. DOI: 10.1080/01402390701432046.

Feng, H. 2015. "The new geostrategic game: Will China and Russia form an alliance against the united states?" DIIS. Available online at: https://www.diis.dk/en/research/the-new-geostrategic-game. Accessed 11 Mar. 2019.

Ferguson, C. 2012. "The Strategic Use of Soft Balancing: The Normative Dimensions of the Chinese-Russian 'Strategic Partnership"”. Journal of Strategic Studies 35(2): 197-222. DOI: 10.1080/01402390.2011.583153.

Garnett, S. 2001. "Challenges of the Sino-Russian strategic partnership." The Washington Quarterly 24(4): 41-54. DOI: $10.1162 / 016366001317149174$.

Konings, P. 2007. "China and Africa." Journal of Developing Societies. 23(3): $341-367 . \quad$ DOI 10.1177/0169796X0702300303.

Korolev, A. 2018. "On the Verge of an Alliance: Contemporary China-Russia Military Cooperation." Asian Security pp.1-20. DOI: 10.1080/14799855.2018.1463991.

Korolev, A. and Portyakov, V. (2018). Reluctant allies: System-unit dynamics and China-Russia relations. International Relations. DOI: $10.1177 / 0047117818812561$.

Li, C. 2007. "Limited Defensive Strategic Partnership: Sino-Russian rapprochement and the driving forces." Journal of Contemporary China, 16(52): 477-497.

Lo, B and Rothman, A. 2006. "China and Russia: Partners with Tensions." Institute of Policy Studies. Available at: https://www.ips.org.pk/china-and-russia-partners-with-tensions/. Accessed 07 Mar. 2019.

Lo, B. 2008. Axis of convenience. Washington, D.C.: Brookings Institution Press.

Malle, S. 2017. "Russia and China in the 21st century. Moving towards cooperative behaviour." Journal of Eurasian Studies 8(2): 136-150. https://doi.org/10.1016/j.euras.2017.02.003

Nezhnikova, E., Papelniuk, O. and Gorokhova, A. 2018. "Russia-China Energy Dialogue: Research of the Most Promising Energy Areas for Interrelation." Econpapers.repec.org. Available at: https://econpapers.repec.org/RePEc:eco:journ2:2018-01-25. Accessed 09 Mar. 2019.

Oznobishchev, S. 2017. "Russia and China: Expectations, illusions, and reality." Asian Journal of Comparative Politics 2(1): 40-54. DOI: 10.1177/2057891116662710.

Portyakov, V. 2010. "Russian-Chinese Relations: Current Trends and Future Prospects, Moscow." Russian Analytical Digest $73 / 10$.

Røseth, T. 2017. "Russia's energy relations with China: passing the strategic threshold?" Eurasian Geography and Economics 58(1): 23-55. DOI: 10.1080/15387216.2017.1304229.

Schwartz, P. 2014. "Evolution of Sino-Russian Defense Cooperation since the Cold War." The Asan Forum. Available at: http://www.theasanforum.org/evolution-of-sino-russian-defense-cooperation-since-the-cold-war/. Accessed 05 Mar. 2019. 
Scobell, A., Ely Ratner, and Michael Beckley. 2014. "China's Strategy toward South and Central Asia.” RAND Corporation, 2014 , 38-39. Available http://www.rand.org/content/dam/rand/pubs/research_reports/RR500/RR525/RAND_RR525.pdf.

Weezerman, S. 2017. "China, Russia and the shifting landscape of arms sales." SIPRI. Available at: https://sipri.org/commentary/topical-backgrounder/2017/china-russia-and-shifting-landscape-arms-sales. Accessed 09 Mar. 2019.

Weitz, R. 2008. China-Russia security relations: Strategic parallelism without partnership or passion? Carlisle, PA: Strategic Studies Institute.

Weitz, R. 2014. "The Russia-China Gas Deal: Implications and Ramifications." Hudson.org. Available at: https://www.hudson.org/research/10590-the-russia-china-gas-deal-implications-and-ramifications. Accessed 10 Mar. 2019.

Weitz, R. 2015. "Parsing Chinese-Russian Military Exercises,” Strategic Studies Institute, April 15, 2015 , 5-32. Available at: http://www.strategicstudiesinstitute.army.mil/pdffiles/PUB1266.pdf.

Yu, Bin. 2014. "China-Russia Relations: Navigating through the Ukraine Storm." Comparative Connections, September 2014. Available at: http://csis.org/files/publication/1402qchina_russia.pdf. 